\title{
THE MYTH OF THESEUS IN PLATO'S PHAEDO
}

\section{Futter (University of the Witwatersrand)}

According to Phaedo Socrates spent a long time in prison after his trial because no executions could be carried out during the time of a religious festival. This festival had its origins in the myth of Theseus and the Minotaur. The Athenians had vowed to Apollo that if Theseus and his companions were saved 'they would send a mission to Delos every year' (58b2-3).

What is the relevance of the myth of Theseus and the Minotaur for an interpretation of Phaedo? This paper argues that the dialogue evokes three different re-enactments of the Theseus myth. The first is the Athenian delegation to Delos (58a). The second is the trial and execution of Socrates. The third is Socrates' struggle against the fear of death. Each of these re-enactments can be understood as an attempt at spiritual purification. Both Socrates and the Athenians are in different ways purifying themselves by re-enacting the myth of Theseus. These different modes of catharsis are implicitly evaluated by the eschatological myth which Socrates presents just before his death.

\section{Introduction}

At the beginning of the Phaedo, Echecrates asks why Socrates died so long after being sentenced to death (58a5). Phaedo answers that Socrates' trial took place on the day before an Athenian religious festival (58a6-8; $c f$. 61a). This festival had its origins in the myth of Theseus and the Minotaur. The Athenians had made a vow to Apollo that if Theseus and his companions were saved 'they would send a mission to Delos every year' $(58 \mathrm{~b} 2-3){ }^{1}$

What is the relevance of the Theseus myth for an interpretation of Phaedo? One proposed answer to this question is that Socrates is being presented as the 'new and true Theseus' struggling with 'the monster called Fear of Death'. Although this interpretation is correct as far as it goes, it does not, I believe, go far enough. Close attention to the relationship between the mythical subtext and the actions reported in the dialogue reveals that Socrates is both Theseus and Minotaur, though considered from different points of view. Socrates and the

1 Unless otherwise indicated, the translation of Phaedo is by G M A Grube, as reprinted in Cooper 1997.

2 Klein 1965:126; Klein 1975:2. See also Dorter 1982, Burger 1984, Bacon 1990, Madison 2002, Clayton 2009 and Brann 2011. 
Athenians are in different ways purifying themselves and fulfilling an obligation to Apollo by re-enacting Theseus's voyage.

\section{Elements: Dialogue, myth, narrative}

The Phaedo is a dramatisation of a conversation between two philosophers, Phaedo and Echecrates. This conversation is set in the Peloponnesian city of Phlius (57a7), at some indeterminate time after Socrates' death. ${ }^{3}$ I will refer to this conversation as the framing dialogue. ${ }^{4}$

The framing dialogue begins with Echecrates asking Phaedo whether he was present with Socrates on the day he drank the poison or whether he learnt about the event from someone else (57a1-3). Phaedo says that he was himself present (57a4). Echecrates next asks him to recount how Socrates died and what he said before he died (57a5-6). Phaedo responds by inquiring whether the Phliasians had heard about what had happened at Socrates' trial (58a1-2). Echecrates says that they had heard a report; but he is moved to ask why Socrates died so long afterwards (58a3-4). The reason, Phaedo explains, was chance ( $\tau \dot{\chi} \chi \eta)$ : the festival of Apollo commemorating Theseus's liberation of fourteen young Athenians had begun on the day before the trial (58a6-c5). I shall refer to the myth of Theseus and the Minotaur as the dialogue's mythical subtext.

Echecrates again repeats his request that Phaedo give an account of what Socrates said and did before he died, but now adds a further question about the identity of those who were with him until the last (58c6-9). Phaedo answers with a description of how he and the others present were affected by witnessing the death of a friend (58e1-59b1). He then lists the names of Socrates' companions, both those who were in attendance, and also some notable absentees (59b6-c6). ${ }^{5}$ Eventually, in response to Echecrates's reformulated question about the content of

3 D Nails claims that the framing conversation is set a few weeks or months after the execution (2002:323). This seems incorrect. As W A Johnson points out, Echecrates's remarks that 'hardly anyone from Phlius visits Athens nowadays' (57a7), and 'nor has any stranger come from Athens for some time who could give us a clear account of what happened' (57a8-b2), imply that 'Phaedo's arrival in Phlius comes at a significant temporal distance from Socrates' death' (1998:578).

4 This frame is interrupted at $88 \mathrm{c}-89 \mathrm{a}$ and $102 \mathrm{a}$ but is not closed at the end of the dialogue. Although "this lack of closure might make "frame" seem like the wrong word ... there is a larger sense in which the initial scene-setting "frames" the whole conversation, by providing the imaginative context within which it is situated' (Blondell 2002:47 n.148).

5 Most famously: 'Plato, I believe, was ill' (59b10). Aristippus and Cleombrotus were said to be in Aegina (59c4). 
the conversation, Phaedo delivers a lengthy third-person report (59c8-118a17), ${ }^{6}$ which I shall term the primary narrative, with a view to telling everything 'from the beginning' (59c8). The primary narrative begins in the morning of Socrates' death day (59c) and continues until early evening (116e), reporting, amongst other things, the philosophical discussion about the soul's immortality, the manner in which Socrates handled himself, his kindness toward his friends, his courage in the face of death, and even his physical reaction to the hemlock. In addition, Phaedo reports Socrates' telling of an eschatological myth in which the fate of the souls of the dead is described (107c-114c). I shall refer to the world portrayed in the myth as the spiritual world. ${ }^{7}$

Given this sketch of the dialogue's dramatic, narrative, and mythical elements, the question of the relevance of the Theseus myth for an interpretation of Phaedo can be understood as a question about how the actions of the dialogue's mythical subtext connect to the actions and events of the framing dialogue, primary narrative, and spiritual world. My focus in $\$ \S 3-4$ will be on the relationship between the mythical subtext and the primary narrative; the connections between primary narrative and spiritual world, as well as the significance of the framing dialogue, will be discussed briefly in $§ 5$ and $\S 6$ respectively.

\section{Myth and primary narrative I}

The primary narrative reports the actions and events occurring in the prison house in Athens on Socrates' death day. This sequence of actions and events can be understood from the perspective of Socrates or Athens as agent. When considered from this dual perspective it becomes evident that the dialogue alludes to or presents at least three different re-enactments of the myth of Theseus and the Minotaur.

From the Athenian point of view, the day of the primary narrative is the day of Socrates' execution. The execution is said to be carried out on the day after the Athenian delegation returned from Delos (59e; cf. Crit. 43c-44b). The ship for the delegation to Delos was wreathed on the day before Socrates' trial (58a7). Hence the dialogue explicitly connects the trial and execution of Socrates to some central events in the Athenian liturgical calendar. ${ }^{8}$

6 'The third-person narrative of the events in the prison continuously recalls to mind that the central dialogue is in the voice of Phaedo' (Johnson 1998:580).

7 By 'spiritual' I mean 'concerning the soul'.

8 Since Socrates' trial took place on the day after the embassy departed for Delos (58a7) and Plutarch says that the Athenians 'still now' commemorate Theseus's departure on the $6^{\text {th }}$ day of Mounichion (Thes. 18.2), Socrates' trial can be dated to 7 Mounichion. If Xenophon is accurate in his report that Socrates was 'forced to live for thirty days after 
The embassy to Delos is part of a religious festival. The Athenians commemorate Theseus's voyage to Crete and keep a vow to Apollo by sending the embassy to Delos (58a-b). They sail in the 'the ship in which, [they] say, Theseus once sailed to Crete, taking with him the "seven pairs"" (58a-b). The embassy is then a ritualistic recreation of the original myth. The Athenians re-enact the voyage of Theseus by undertaking a voyage to Delos in what they claim to be Theseus's actual ship (58a10).

The ritual remembrance of Theseus's voyage is closely associated with two other rituals which derive their meaning, at least in part, from the Theseus myth. The wreathing of the ship by the priest (58c1-2) which inaugurated the mission to Delos was the culmination of a festival of Apollo called the Delphinia. H W Parke explains:

On the $6^{\text {th }}$ of Munichion there was a procession of the maidens of Athens to the Delphinion, the shrine on the bank of the Illisos near the Olympeion, where both Apollo and Artemis were worshipped. The girls went to make supplication and so carried boughs of the sacred Athenian olive bound with white wool. ${ }^{9}$

The Delphinia repeated one of Theseus's actions before his departure to Crete. For, according to Plutarch, Theseus 'went to the Delphinium' after having received those selected for sacrifice to the Minotaur, and 'made an offering for them to Apollo of his suppliant's badge, which was a bough of a consecrated olive tree, with white wool tied about it' (Thes. 18.1).

The Athenian delegation to Delos was headed to another festival, which Xenophon calls the Delia (Mem. 4.8.2). ${ }^{10}$ Many of the major Athenian festivals were connected with Theseus; this one, although a Pan-Hellenic affair, was no exception. Plutarch explains:

Now Theseus, in his return from Crete, put in at Delos, and having sacrificed to the god of the island, dedicated to the temple the image of [Aphrodite] which Ariadne had given him, and danced with the young Athenians a dance that, in memory of him, they say is still preserved among the inhabitants of Delos, consisting in certain measured turnings and returnings, imitative of the windings and twistings of the labyrinth ...

the verdict was given' (Mem., 4.8.2), it will follow that the Athenian delegation returned from Delos on the $5^{\text {th }}$ day of Thargelion and Socrates died on the $6^{\text {th }}$ day of Thargelion 399 BC. This reasoning is elaborated by White 2000:155 ff.

9 Parke 1977:137.

10 For some difficulties in understanding the relation between the annual mission to Delos and the Greater Delia, see White 2000:170-171 nn. 27\&29. 
They say also that he instituted games in Delos, where he was the first that began the custom of giving a palm to the victors (Thes. 21.2; italics added).

Given this account, it seems plausible to think that Theseus's actions in Crete were ritually expressed at the Delian festival to which the Athenian embassy was headed. It is reasonable to suppose, more specifically, that the Athenians would have re-enacted Theseus's encounter with the Minotaur in the labyrinth by means of the crane dance ( $\gamma \varepsilon \dot{\varepsilon} \rho \alpha v o \zeta$ ) around the famous Ceratonian altar (Thes. 21.2). But even if this is doubted, the general point that the Athenians commemorated Theseus's conquest of the Minotaur in ritual seems perfectly secure. In the month leading up to Socrates' death the Athenians self-consciously re-enact the events of the original Theseus myth.

On the $6^{\text {th }}$ day of Mounichion, ${ }^{11}$ the Athenians celebrated the Delphinia to commemorate Theseus's departure to Crete. The festival culminated with the priest's crowning of Thesesus's ship. On the next day, the $7^{\text {th }}$ of Mounichion, the Athenians initiated two chains of action: they set sail for Delos; they put Socrates on trial, convicted him, and sentenced him to death. Socrates was put on trial because he was considered a danger to the city. He was accused of, and ultimately convicted on, charges of destroying the young men

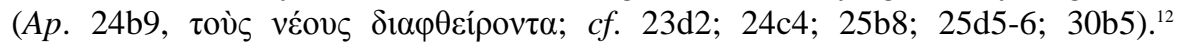
During the period defined by the original myth, therefore, a period in which they were ritually remembering Theseus's attempt to save the 'twice seven', the Athenians confronted a new danger. They fought for their young people by bringing Socrates to trial, convicting him and sentencing him to death. Thereafter they incarcerated him for thirty days. The Cretan labyrinth was, of course, a prison house. Hence it seems that during the time in which they celebrated Theseus's voyage to Crete and slaying of the Minotaur, the Athenians acted once more in defence of their young people. The trial of Socrates can be understood as an Athenian confrontation with a new Minotaur.

According to the primary narrative, on the day after Theseus's ship returns from Delos, Socrates is surrounded by fourteen named individuals, 'twice seven' ( $\delta i \varsigma$ غ̇ $\pi \tau \alpha \dot{\alpha} ; 58 \mathrm{a})$. Phaedo indicates the numerical correspondence very precisely: ${ }^{13}$

Among the local people there was Apollodorus, whom I mentioned, Critobulus and his father, also Hermogenes, Epigenes, Aeschines

\footnotetext{
11 See note 8 .

12 The other part of the formal indictment had to do with the introduction of new gods into the city. See $A p$. 24b.

13 This point is made by Klein 1975:2.
} 
and Antisthenes. Ctesippus of Paeania was there, Menexenus and some others. Plato, I believe, was ill.

Were there some foreigners present?

Yes, Simmias from Thebes with Cebes and Phaedondes, and from Megara, Euclides and Terpsion.

What about Aristippus and Cleombrotus? Were they there?

No. They were said to be in Aegina.

Was there anyone else?

I think these were about all. (59b6-c6)

In naming those present with Socrates in the prison house, Phaedo begins by mentioning seven Athenians. He then mentions two further Athenians, Menexenus and Ctessippus. ${ }^{14}$ This makes nine. As if to emphasise the count, Plato has Phaedo mention that he, Plato, was not in attendence (59b10). Echecrates next asks whether any foreigners were present. Phaedo enumerates five. Again, as if to highlight the point, Plato has Echecrates ask whether Aristippus and Cleombrotus were there, to which Phaedo answers in the negative. Socrates is surrounded by fourteen youths: twice seven. There are nine Athenians, and five foreigners, thereby matching exactly the nine young men and five young women who accompanied Theseus to Crete. ${ }^{15}$

On the day after the delegation returns from Delos, the Athenians enter into the labyrinth, by means of representatives, to kill Socrates. In the execution scene of the primary narrative, Phaedo pictures Socrates looking up like a bull (117b5). Hence he depicts a man with a bull head, that is, a Minotaur. ${ }^{16} \mathrm{He}$ thus recalls the Theseus myth, by reference to which he began his narration (58a). Hence it is reasonable to say that Phaedo's primary narrative tells how the Athenians saved themselves and their young men from destruction by Socrates, a spiritual Minotaur.

In summary, I have argued that the Athenians play out the actions of the original Theseus myth in two different ways. They self-consciously re-create

14 Although Phaedo adds at 59b9-10 that other local people were present, this does not undermine the precise numerical correspondence of named individuals. 'The fact that these [other] persons are unnamed is itself significant, since ... naming is a basic means of social individuation' (Blondell 2002:68). Klein 1975:2 identifies the unnamed others with Theseus's crew.

15 Theseus replaced two of the seven maidens with effeminate young men. See Plutarch, Thes. 23.2. It is noteworthy that Phaedo does not include himself in the number of those present. I return to this point in $\$ 6$ below.

16 For more on the interpretation of the bull simile, see Futter 2014. 
Theseus's voyage to Crete in order to keep a vow to Apollo. And they also carry out another series of actions which does not self-consciously imitate Theseus but merely, as it were, unconsciously repeats the actions of the original myth. From this perspective, the actions and events of Phaedo's primary narrative show the Athenian overcoming of Socrates, a new and true Minotaur, and the liberation of fourteen young men.

\section{Myth and primary narrative II}

On the $6^{\text {th }}$ day of Thargelion, $399 \mathrm{BC}$, the Athenians imitate Theseus's conquest of the Minotaur by executing Socrates. But the Athenians are not the only ones reenacting an old myth. For Socrates is doing the same, albeit in a quite different way.

Phaedo's primary narrative locates Socrates in a prison house along with fourteen named young men. The jailhouse symbolises the labyrinth, and the fourteen represent the $\delta i \varsigma \dot{\varepsilon} \pi \tau \alpha$. As discussed in $\S 3$, this scene can be understood from the Athenian perspective as an image of the Minotaur in the labyrinth along with fourteen victims. But from a Platonic perspective of Socrates as agent, the situation is rather different. From this point view, Socrates is not the Minotaur, but Theseus, slayer of the Minotaur, and liberator of the fourteen. This claim can be supported by a psychological interpretation of Socrates' philosophical activity in the dialogue, the activity in which Apollo commanded him to spend his life (Ap. 28e-29a; Phd. 60d-61b).

Socrates' activity of philosophy is linked to the Theseus myth by a set of three 'equations'. The equations are that the body is 'a kind of prison' $(62 \mathrm{~b}$; 81e; 92a); that philosophy involves separating the soul from the body (67d); and that pleasure and pain are like pins or rivets which keep the soul attached to the body (83d). When the events of the primary narrative are considered in relation to these equations, Socrates' dialectical activity can be seen to instantiate the Theseus myth at the level of the soul.

In the original myth, the young Athenians are trapped in the labyrinth and killed by the Minotaur. In the Socratic version, the labyrinth, a prison house, is the body. The soul's imprisonment in the labyrinth is its entrapment in the body (82e). The most likely candidate for the identity of the Minotaur is the fear of death (77e). ${ }^{17}$ The Minotaur is a mingled form ( $\sigma 0 ́ \mu \mu \varepsilon 1 \kappa \tau o v ~ \varepsilon i \tilde{\delta o s}$, Plutarch, Thes. 15.2); so too the fear of death: It is the conjunction of an awesome pain (fear) and a sort

17 See Klein 1975:2. Cf. Burger 1984:13 and Brann 2011:31. 
of hobgoblin (77e).$^{18}$ The fear of death is dangerous because it inclines one to despair, that is, spiritual death. ${ }^{19}$

In order to escape from the labyrinth, Theseus must overcome the Minotaur. In order to escape from the body, Socrates must defeat the fear of death. The withdrawal and escape from the body is achieved through philosophy $(82 \mathrm{dff}$.).

The lovers of learning know that when philosophy gets hold of their soul, it is imprisoned in and clinging to the body, and that it is forced to examine other things through it as through a cage and not by itself, and that it wallows in every kind of ignorance (82d9-82e5).

Philosophy then persuades the soul to withdraw from the senses in so far as it is not compelled to use them and bids the soul to gather itself together by itself, to trust only itself and whatever reality, existing by itself, the soul by itself understands ... (83a6-b2).

Hence it seems that Socrates' practice of philosophical dialectic on his last day is designed to liberate the soul from the labyrinth of the body and overcome the Minotaur of fear which threatens to destroy him. ${ }^{20}$

Socrates successfully overcomes the fear of death by means of philosophy. Phaedo's report is clear:

[The executioner] held out the cup to Socrates, who took it very cheerfully ... without a tremor or any change in colour or expression, but giving the man his usual bull-like look, asked: 'What do you say about pouring someone a libation from this cup?' (Phd. 117b3-7; my translation).

Since fear is associated with physical signs such as paling, trembling, or attempting to run away, Phaedo indicates with dramaturgical precision that Socrates does not fear. Theseus's slaying of the Minotaur is spiritually reinterpreted and re-enacted in Socrates' overcoming of the fear of death. ${ }^{21}$

In the original myth, Theseus saves his companions by killing the Minotaur. As Phaedo puts the point in the framing dialogue: 'he saved them and was himself saved' (58b1). Socrates' task in the dialogue is also formulated in these terms.

18 Cf. Klein 1975:2, 4. The word translated 'hobgoblin' is $\tau \grave{\alpha} \mu о \rho \mu о \lambda v ́ \kappa \varepsilon 1 \alpha$, a word

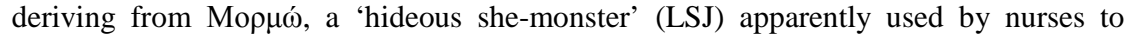
frighten children.

19 This interpretation is defended in Futter, forthcoming.

20 On despair as psychological destruction or disintegration, see Futter, forthcoming.

${ }^{21}$ On the meaning of the conflation of Socrates and Minotaur in Socrates' bull-look, see Futter 2014:6-7. 
After the completion of his initial apologia against the charge of excessive frivolity in the face of death, Cebes intervenes:

Socrates, he said, everything else you said is excellent, I think, but men find it very hard to believe what you said about the soul. They think that after it has left the body it no longer exists anywhere, but that it is destroyed and dissolved on the day the man dies, as soon as it leaves the body; and that, on leaving it, it is dispersed like breath or smoke, has flown away and gone and is no longer anything anywhere (69e7-70b4).

Socrates presents two arguments in response. After further resistance from his interlocutors, he says:

I think you and Simmias would like to discuss the [logos] more fully. You seem to have this childish fear that the wind would really dissolve and scatter the soul, as it leaves the body, especially if one happens to die in a high wind and not in calm weather (77d5-e2).

Cebes laughs and says:

Assuming that we [are] afraid, Socrates, try to change our minds, or rather do not assume that we are afraid, but perhaps there is a child in us who has these fears; try to persuade him not to fear death like a [hobgoblin] (77e;

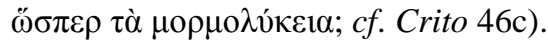

Socrates' response is notable:

You should ... sing a charm over him every day until you have charmed away his fears (77e8-9).

Cebes' self-correction - from 'we are afraid' to 'a child in us is afraid' indicates that Socrates' logoi are not intended to operate purely at the level of reason and evidence. They are explicitly therapeutic, a kind of charm for his interlocutors' fears, and we might suppose, his own ( $c f .58 \mathrm{e} 1-59 \mathrm{~b} 1)$.

In the Platonic version of the Theseus myth, Socrates can't save his companions by expunging their fear of death. He cannot defeat the Minotaur for others. He can only help them to overcome their own fears. The point is exhibited vividly in the dialogue. Whereas Socrates went to his death with a joke, Phaedo and the twice-fourteen do not overcome the fear of death, that is, the fear of Socrates' death. Consider Phaedo's description of what occurs after Socrates drinks the poison 'calmly and easily' (117c4-5): 
Most of us had been able to hold back our tears reasonably well up till then, but when we saw him drinking it and after he drank it, we could hold them back no longer; my own tears came in floods against my will. So I covered my face. I was weeping for myself, not for him - for my misfortune in being deprived of such a comrade. Even before me, Crito was unable to restrain his tears and got up. Apollodorus had not ceased from weeping before, and at this moment his noisy tears and anger made everybody present break down, except Socrates (117c5-d6).

The victory over the fear of death is not something that can be achieved for anyone else. It is also, for that matter, not something that can be achieved once and for all: 'one has to sing a charm over him every day' (77e8-9).

\section{Catharsis}

In the previous section, I argued that Socrates and the Athenians are both fulfilling an obligation to Apollo by re-enacting Theseus's voyage. In this section, I argue that each re-enactment of Theseus's voyage should be understood as an attempt at spiritual purification ( $\kappa \alpha \dot{\theta} \theta \rho \sigma \iota)$ ). The reader is presented with two different modes of purification the merits of which are implicitly evaluated by the organisation of the spiritual world charted out in the eschatological myth which Socrates presents just before his death.

The primary narrative tells of the actions and events of Socrates' last day, from early morning until he drinks the hemlock in the early evening. The events of this day are positioned in relation to the Athenian festival of Apollo and Socrates' trial (58a3-c5), both of which can be understood in terms of the concept of catharsis. With regard to the first, the Athenians attempt to purify themselves during the time of the festival, and perhaps more substantially, by conducting that ritual. They 'have a law to keep the city pure, and no execution may take place once the mission has begun until the ship has made its journey to Delos and returned to Athens' (58b; italics added; $c f$. 61a). ${ }^{22}$ With regard to the second, the Athenians put Socrates on trial because they are concerned about the moral and spiritual well being of the city. While Socrates thought of his philosophical mission as benefitting his fellow citizens (Ap. 30a-b), the Athenians believed otherwise. They thought that they were expelling a corruptor of the young; this is, it appears, a mode of catharsis or purification ( $c f$. Euthyp. 2c-d).

22 Moreover, the celebration of the Delphinia which culminated in the wreathing of Theseus's ship would also seem to be linked with purification since the suppliants to Apollo carried sacred olive branches covered with white wool (Plutarch, Thes. 18.1). 
The idea that the Athenians were purifying themselves by executing Socrates can be developed further. Given the dating of Socrates' trial outlined above, Theseus's ship would have returned from Delos on the $5^{\text {th }}$ of Thargelion, on the day before the start of another important festival of Apollo, called the Thargelia. ${ }^{23}$ The Thargelia was scapegoat ritual: the Athenians would select, feed and expel a course, a matter of purification, of some designated people carrying guilt in order to secure the spiritual health of others. ${ }^{24}$ Parke explains as follows:

The form of purification used for [the] public ritual ... consisted in what were known as Pharmakoi - persons whose title implied that they possessed magical properties. In Athens two men were chosen each year, the qualification being that they should be ugly and poor ... These Pharmakoi were fed for some time at the state's expense, and on the first day of the Thargelia they were led out to act as scapegoats for the people of Athens. ${ }^{25}$

Socrates seems to fulfil the requirements for being a $\varphi \alpha \rho \mu \alpha \kappa o$ s rather well, on account of his well-known poverty and physical ugliness, and the fact that he was in prison 'fed for some time at the state's expense'. ${ }^{26}$ At the very least, and this is not a matter of speculation, Socrates is executed on the day of catharsis. ${ }^{27}$ 'The $6^{\text {th }}$ [of Thargelion] was a day of purification'. ${ }^{28}$ So it would seem that the Athenian

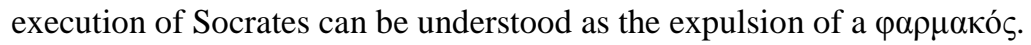

The events of the primary narrative, considered from Socrates' perspective, can also be understood in terms of кá $\theta \alpha \rho \sigma i \varsigma$. This can be accomplished relatively easily by recalling Socrates' contention, already familiar from earlier discussion, that philosophy is a mode of psychic purification. The theme of purification comes to the fore in the discussion of philosophy as a practice of dying (64a ff.). Since death is defined as the separation of the soul from the body, the philosopher is engaged in a kind of dying in as much as he withdraws from body. The body is an

23 Cf. White 2000:157.

24 See Bremmer 1983.

25 Parke 1977:146. This would also connect Socrates with Aesop (Phaedo 60c-d) who was

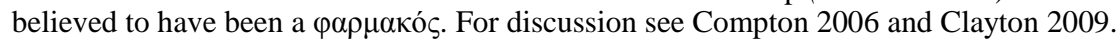

26 He thus received the very sentence 'he proposed at his trial', viz. 'free meals for life' (White 2000:157). In addition, when Socrates says, at 61c1, 'I am leaving today, as the Athenians so order it', he treats his execution like expulsion.

27 The second day of the festival, the $7^{\text {th }}$ of Thargelion, was different. It culminated with a sacrifice. It is tempting to link this sacrifice with Socrates' dying request to Crito that he make a sacrifice to Asclepius (118a).

28 Parke 1977:146. 


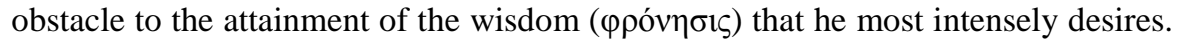
As Socrates says:

While we live, we shall be closest to knowledge if we refrain as much as possible from association with the body and do not join with it more than we must, if we are not infected with its nature but purify ourselves from it until the god himself frees us. In this way we shall escape the contamination of the body's folly; we shall be likely to be in the company of people of the same kind, and by our own efforts we shall know all that is pure, which is presumably the truth, for it is not permitted to the impure to attain the pure' (67a2-b2; italics added).

He continues:

And does purification not turn out to be what we mentioned in our argument some time ago, namely, to separate the soul as far as possible from the body and accustom it to gather itself and collect itself out of every part of the body and to dwell by itself as far as it can both now and in the future, freed, as it were, from the bonds of the body? ... It is only those who practice philosophy in the right way, we say, who always most want to free the soul; and this release and separation of the soul from the body is the preoccupation of the philosophers? (67c5-d10).

The activity of philosophy is said to purify the soul. Socrates' practice of philosophy as reported in the primary narrative and the theme of catharsis are therefore closely linked: Socrates purifies his soul by doing philosophy. Presumably this point applies also to the joint activity of philosophical dialogue. Socrates tries to help others purify themselves by sharing the logos with them. ${ }^{29}$

If the above reasoning is correct, then Socrates and the Athenians are, by their recreations of Theseus's voyage, engaged in rituals of purification. But they have a radically different understanding of what purification involves and requires. For Socrates, purification is philosophical dialectic, whereas for the Athenians, it is adherence to a set of civic rituals. Their respective re-enactments of the Theseus myth in dialectic or civic rituals are then correlated with different positions in the topography of the spiritual world as mapped out by Socrates' concluding eschatalogical myth.

The myth with which Socrates' final conversation is brought to completion offers a picture of the soul's journey after death. According to the myth (113d ff.), the soul of each dead person is transported to a place of judgment. At this place, the soul is judged on the basis of its nature, whether it has lived beautifully or

29 On the Platonic dialogue as ritual of transformation, see Adluri 2006. 
piously, or not. Those who have lived an 'average' life (113d4) are sent to the Acherusian Lake for purification; those who are judged incurable are hurled into Tartarus, never to emerge (113e1-6); those who are found guilty of grave but curable offenses must fall into Tartarus for a year, and thereafter try to persuade those they have wronged to allow them back (113e6-114b6). Of the souls who are 'released from the regions of the earth as from a prison' (114b8-9), there are also two groups: the members of the first group, who have lived exceptionally holy lives, are sent to the surface of the earth, whereas those who have purified themselves by philosophy to even more beautiful places, where they live altogether without bodies (114c3-4). The spiritual world is thus ordered by a principle of justice: people are judged according to the purity of their souls and allocated forms (cf. 81e-82c) and places which properly reflect the lives they have lived.

When the myth which ties the fortunes of the soul to its relative state of purity is considered in relation to the actions of Socrates and the Athenians in the primary narrative, it seems to offer an evaluation of the two different re-enactments of the Theseus myth considered as rites of purification. The eschatological myth validates the Socratic re-enactment of the Theseus myth because it justifies the philosophical form of catharsis. The philosopher fares best in the afterlife because he has purified himself with philosophy. By contrast, the civic form of purification practiced by the Athenians would seem to produce a kind of culpable ignorance which secures for them a place in Tartarus with those guilty of great but curable crimes (113e6-7; cf. Ap. 41d-42a; Rep. 619b ff.).

\section{The framing dialogue}

I am now able to return, very briefly, to the relationship between the framing dialogue and the mythical and narrative elements of the text.

In the framing dialogue Phaedo establishes the mythical backdrop against which the events and actions of the primary narrative are to be interpreted. He also suggests to the reader an interpretation of Socrates as new Theseus and, if the above argument is accepted, juxtaposes the historical actions of the Athenians with their mythical past in such a way as to permit the reader to discern the ways in which the Athenian actions reported, or alluded to, replay the actions of the original myth. Hence the framing dialogue binds the events and actions of the primary narrative to the mythical subtext.

There is also a sense in which the framing dialogue not only establishes the mythical subtext but is also incorporated by it. The reporter of the primary narrative, Phaedo, is himself an agent in the primary narrative, and hence figures in the re-enactment of the original myth that the narrative plays out. In his answer to Echecrates's question about the identity of those present with Socrates on his last 
day, Phaedo carefully enumerates the names of fourteen young men, twice seven (59b6-c6), but excludes himself. If Phaedo can be identified with a figure in the original myth, he would seem to be Ariadne ${ }^{30}$ not a member of the 'twice seven', but a helper, someone who assists Socrates at his most dangerous hour, when the $\log o s$ is about to die $(89 \mathrm{~b} \mathrm{ff}$.). This identification is supported by two further considerations. First, Socrates displays overt affection for him in the dialogue, stroking his head and beautiful hair (89b), an action which recalls Homer's

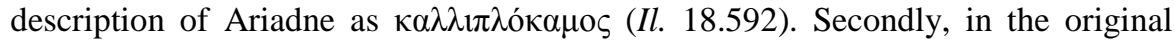
myth Theseus abandons Ariadne on the return voyage from Crete. The dialogue seems to preserve this connection; for it is plain that Phaedo is - in some sense, at least - without Socrates. He has been left behind. This theme, of Socrates' willingness to depart and leave his friends behind, is prominent in the dialogue (63a). For these reasons, it seems plausible to say that in the Socratic recreation of the Theseus myth, Phaedo is the new Ariadne.

In the original myth, Ariadne helps Theseus by giving him a ball of yarn which enables him to escape the labyrinth. In the Socratic retelling of the Theseus myth, escape from the labyrinth is equated with escape the body. Ariadne's thread must in the symbolic retelling of the myth refer to that which Phaedo gives to Socrates in order to facilitate his escape from the body. When considered in this way Ariadne's thread would appear to correspond with the primary narrative of the dialogue. ${ }^{31}$ Phaedo's narrative enables Socrates to live without the body in a sense; it enables Socrates to live for us today.

In summary, the framing dialogue holds everything together. The speech acts of Phaedo and Echecrates in the city of Phlius at some indefinite time after Socrates' death connect the original myth of Theseus and the Minotaur to the actions of Socrates and the Athenians inside the prison of Athens on the $6^{\text {th }}$ of Thargelion $399 \mathrm{BC}$ and also to journey of the individual soul in the afterlife. ${ }^{32}$

\section{BIBLIOGRAPHY}

Adluri, V 2006. Initiation into the Mysteries: The experience of the irrational in Plato. Mouseion 6:407-423.

Bacon, H 1990. The poetry of Phaedo. http://repositories.cdlib.org/ucbclassics/ctm/festschrift11.

30 Burger 1984:19, Klein 1975:2.

31 Klein 1975:10.

32 I would like to express my gratitude to Hansie Wolmarans, Sjarlene Thom, and two anonymous referees for Akroterion whose insightful comments have helped me to improve this paper. 
Blondell, R 2002. The play of character in Plato's dialogues. Cambridge: Cambridge University Press.

Brann, E 2011. Socrates' legacy: Plato's Phaedo. In Brann, E, Kalkavage, P \& Salem E (eds.), The music of the Republic: Essays on Socrates' conversations and Plato's writings, 3-36. Philadelphia: Paul Dry Books.

Bremmer, J 1983. Scapegoat rituals in Ancient Greece. Harvard Studies in Classical Philology 87:299-320.

Burger, R 1984. The Phaedo: A Platonic labyrinth. New Haven, Conn.: Yale University Press.

Clayton, E 2009. The death of Socrates and the life of Aesop. Ancient Philosophy 28:311-28.

Compton, T 2006. Victim of the muses. Cambridge, MA: Center for Hellenic Studies.

Cooper, J 1997. Plato: Complete works. Indianapolis / Cambridge: Hackett.

Dorter, K 1982. Plato's Phaedo: An interpretation. Toronto: University of Toronto Press.

Futter, D 2014. Socrates' bull sacrifice. Acta Classica 57:233-240.

Futter, D forthcoming 2015. The death of Socrates. Philosophical Papers.

Grube, G M A 1997. Phaedo. In Cooper J M (ed.), Plato: Complete works, 49-100. Indianapolis: Hackett.

Johnson, W A 1998. Dramatic frame and philosophic idea in Plato. American Journal of Philology 119:577-98.

Klein, J 1965. A commentary on Plato's Meno. University of Chicago Press.

Klein, J 1975. Plato's Phaedo. The College 26:1-10. Reprinted in Williamson, R B \& Zuckerman, E (eds.), Lectures and essays, 1985. Annapolis, Maryland: St. John's College Press. 375-393.

Madison, L A 2002. Have we been careless with Socrates' last words?: A rereading of the Phaedo. Journal of the History of Philosophy 40:421-436.

Nails, D 2002. The people of Plato: A prosopography of Plato and other Socratics. Indianapolis: Hackett.

Parke, H W 1977. Festivals of the Athenians. London: Thames and Hudson.

Plutarch 1914. Lives. Volume 1. Trans. B Perrin. Cambridge, MA: Harvard.

White, S A 2000. Socrates at Colonus: A hero for the Academy. In Smith, N D \& Woodruff, P (eds.), Reason and religion in Socratic philosophy, 151-175. Oxford: Oxford University Press. 